\title{
Isolation and identification of Escherichia coli 0157:H7 from ground beef hamburgers in Khuzestan Province, Iran
}

\author{
Ahmad Farajzadeh Sheikh ${ }^{1,3}$, Soodabeh Rostami ${ }^{1,2}$, Mansour Amin ${ }^{1,3}$, Armaghan Abbaspour $^{4}$, \\ Hamed Goudarzi ${ }^{1,2}$ and Mohammad Hashemzadeh ${ }^{1,2,3 *}$ \\ ${ }^{1}$ Microbiology Department, School of Medicine, Ahvaz Jundishapur University of Medical Sciences, Ahvaz, Iran. \\ ${ }^{2}$ Student Research Committee, Vice-Chancellor for Research Affairs, Ahvaz Jundishapur University of Medical \\ Sciences, Ahvaz, Iran. \\ ${ }^{3}$ Infectious and Tropical Diseases Research Center, Ahvaz Jundishapur University of Medical Sciences, Ahvaz, Iran. \\ ${ }^{4}$ Expert of laboratory, Golestan Teaching Hospital, Ahvaz Jundishapur University of Medical Sciences, Ahvaz, Iran.
}

Accepted 19 December, 2012

\begin{abstract}
Meat products have been implicated in outbreaks of E.coli 0157:H7 in most of the world. This bacterium is associated with diseases such as hemorrhagic colitis, hemolytic uremic syndrome and thrombotic thrombocytopenic purpura. In this study, we used two Conventional methods and Multiplex PCR for the isolation and identification of $E$. coli $0157: \mathrm{H} 7$ from ground beef hamburger samples. In total, 200 fresh ground beef hamburger samples were obtained from different meat factories across Khuzestan Province from March to September 2010. Tryptone- Soya- broth (TSB) supplemented with novobiocine $(20 \mathrm{mg} / \mathrm{l})$ was used as enrichment medium and Tellurite cefixime-sorbitol MacConkey agar (TC-SMAC) was used for the detection of Non-Sorbitol Fermenting bacteria. Biochemical tests were performed on the Non-Sorbitol fermenting (NSF) colonies. Colonies confirmed as $E$. coli were selected as templates for Multiplex PCR method and serotyping. Out of the $\mathbf{2 0 0}$ ground beef hamburger samples, 8 samples (4\%) had positive results for Non-Sorbitol fermenting colonies (NSF). Out of the 8 samples, three (38\%) were confirmed as $E$. coli by biochemical tests. Of the 3 samples, two samples were $E$. coli 0157:H7 based on multiplex PCR and serotyping. The results indicate that hamburgers could be a reservoir of E.coli 0157:H7 in Khuzestan Province. Since this strain is a food-born pathogen, inspection of meat products for this bacterium is recommended.
\end{abstract}

Key words: Hamburger, E. coli O157:H7, multiplex PCR.

\section{INTRODUCTION}

Escherichia coli O157: $\mathrm{H} 7$ (E. coli O157) is an important food-borne pathogen (You et al., 2006; Bai et al., 2010; Olesen and Jespersen, 2010; Hsu et al., 2005) which was first identified as a human enteric pathogen in 1982

*Corresponding author. E-mail: Hashemzadeh70@yahoo.com. Tel: +98-916- 904-3907. Fax: +98-611-3332036.
(You et al., 2006; Dontorou et al., 2003; Lee and Choi, 2006). In North America, serotype O157:H7 alone is responsible for a number of $E$. coli outbreaks involving 75,000 human infections per year (Bai et al., 2010). This serotype is a major cause of hemorrhagic colitis and hemolytic uremic syndrome (HUS) (You et al., 2006; Dontorou et al., 2003; Olesen and Jespersen, 2010; Lee and Choi, 2006). The primary reservoir of this strain is the cattle. Cattle feces are a major source of contamination 
Table 1. List of target genes, sequence of primers, products size (bp).

\begin{tabular}{|c|c|c|c|c|}
\hline Primer & & Sequence & Size (bp) & Reference \\
\hline \multirow[t]{2}{*}{$r f b E$} & $\mathrm{~F}$ & 5'-AAGATTGCGCTGAAGCCTTTG-3' & 497 & 7 \\
\hline & $\mathrm{R}$ & 5'-CATTGGCATCGTGTGGACAG-3' & & \\
\hline \multirow[t]{2}{*}{ flic } & $\mathrm{F}$ & 5'-GCGCTGTCGAGTTCTATCGAGC-3' & 625 & 7 \\
\hline & $\mathrm{R}$ & 5'-CAACGGTGACTTTATCGCCATTCC-3' & & \\
\hline \multirow[t]{2}{*}{ uidA } & $\mathrm{F}$ & 5'-GCGAAAACTGTGGAATTGGG-3' & 252 & 7 \\
\hline & $\mathrm{R}$ & 5'-TGATGCTCCATAACTTCCTG-3' & & \\
\hline
\end{tabular}

of beef, other food products, and water (You et al., 2006; Dontorou et al., 2003; Bai et al., 2010; Olesen and Jespersen, 2010). The illness is often related to the consumption of contaminated and undercooked ground beef. Also Ground beef hamburger can be a source of $E$. coli 0157. Thus surveillance and detection of this bacterium in food and drug laboratories is very important (You et al., 2006; Dontorou et al., 2003; Bai et al., 2010; Olesen and Jespersen, 2010).

This pathogen is identified by classical microbiological diagnostic procedures based on its inability to ferment sorbitol (Lee and Choi, 2006). Several methods from conventional culture methods such as MacConkey agar containing sorbitol instead of lactose (SMAC) to serological assays are used for isolation and identification of $E$. coli O157:H7. Since the conventional methods have low sensitivity and specificity and they will take time, many studies were designed based on molecular techniques such as polymerase chain reaction (PCR) that detect the presence or absence of specific genes (Bai et al., 2010; Al-Ajmi et al., 2006). Many PCR assays have been developed using primers that target specific genes, but combining these primers in a single reaction would be a fast and reliable for determining the presence of the E.coli O157: $\mathrm{H7}$.

In the present study, we assessed the presence of $E$. coli $\mathrm{O} 157: \mathrm{H} 7$ in ground beef hamburger samples using biochemical tests, serological method and a multiplex PCR that simultaneously detect three genes including: fliC (encoding flagellar antigen), $r f b E$ (encoding lipopolysaccharide O-antigen synthesis), and uidA (encoding beta-glucuronidase).

\section{MATERIALS AND METHODS}

\section{Sample collection}

In total, 200 fresh ground beef hamburger samples were obtained from different meat factories across Khuzestan Province from March to September 2010. All samples were randomly collected aseptically in sterile disposable bags and immediately transferred to the laboratory on crashed ice (Dontorou et al., 2003; Jamshidi et al., 2008).

\section{Culture and isolation}

After transferring the samples to the laboratory, they were analyzed without delay. For E.coli O157: $\mathrm{H} 7$ and $\mathrm{O} 157: \mathrm{H}$ - isolation, $25 \mathrm{~g}$ of each sample were placed into $225 \mathrm{ml}$ of Tryptone- Soya- broth (Merck Co., Germany) supplemented with $20 \mathrm{mg} / \mathrm{l}$ novobiocin (Hymedia, India), and were homogenized into a stomacher bag (Model 400 Bags 6041; Seward Ltd, London, UK) for at least $2 \mathrm{~min}$ into a stomacher and then they were incubated at $37^{\circ} \mathrm{C}$ for $16-18 \mathrm{~h}$. The enriched cultures were sub-cultured into Tellurite $(2.5 \mathrm{mg} / \mathrm{L})$ Cefixime (0.05 mg/L) - Sorbitol MacConkey agar (TC-SMAC) (Merck Co., Germany) and incubated at $37^{\circ} \mathrm{C}$ for $24 \mathrm{~h}$. The non Sorbitol fermenting colonies were selected from TC-SMAC plates, and were confirmed by biochemical tests including reaction in triple sugar iron agar, methyl red, Voges- Proskaur, utilization of citrate, maltose and mannitol, production of urease, phenylalanine deaminase, beta- glucuronidase and indole and serotyping for Non Sorbitol Fermenting (NSF) bacteria as E.coli O157:H7as previously described (You et al., 2006; Lee and Choi, 2006).

\section{Multiplex PCR assay}

Presumptive colonies on TC-SMAC confirmed as E. coli were employed as templates for the PCR method. Template DNA was extracted from NSF colonies by using the simple boiling as previously described by Bai et al. (2010). One microliters of the supernatant was employed as template for PCR amplification. The DNA templates were subjected to Multiplex PCR method described previously (Al-Ajmi et al., 2006). E. coli O157:H7 specific primers were used to determine the presence of $r \mathrm{fbE}$, fliC and uidA gene for somatic antigen $\mathrm{O} 157$, flagellar antigen $\mathrm{H} 7$ and $\beta$-glucuronidase as shown in Table 1. The composition of PCR mixture was $50 \mathrm{mM} \mathrm{KCl}$, $10 \mathrm{mM}$ Tris- $\mathrm{HCl}(\mathrm{pH}, 8.3), 1.5 \mathrm{mM} \mathrm{MgCl}_{2}, 200 \mathrm{mM}$ dNTPs, $0.5 \mu \mathrm{M}$ of each primer, $2 \mathrm{U}$ of Taq polymerase and $5 \mu \mathrm{l}$ of DNA template in a final volume of $50 \mu \mathrm{l}$. Amplification was done on a Techene thermo cycler (UK) using the program as below: An initial denaturation at $94^{\circ} \mathrm{C}$ for $5 \mathrm{~min}$, followed by 30 cycles of denaturation at $94^{\circ} \mathrm{C}$ for $45 \mathrm{~s}$, annealing at $65^{\circ} \mathrm{C}$ for $30 \mathrm{~s}$, extension at $72^{\circ} \mathrm{C}$ for $45 \mathrm{~s}$, and final extension at $72^{\circ} \mathrm{C}$ for $5 \mathrm{~min}$. The amplified products were analyzed by electrophoresis on a $1 \%$ agarose gel and visualized by ethidium bromide staining. Results were recorded using the gel documentation system (UVP Systems, UK). Product sizes were identified using a 100 bp DNA ladder. All the reagents were purchased from Sinaclon Company, Tehran, Iran. E. coli O157:H7 ATCC43895, reference strain was used as 


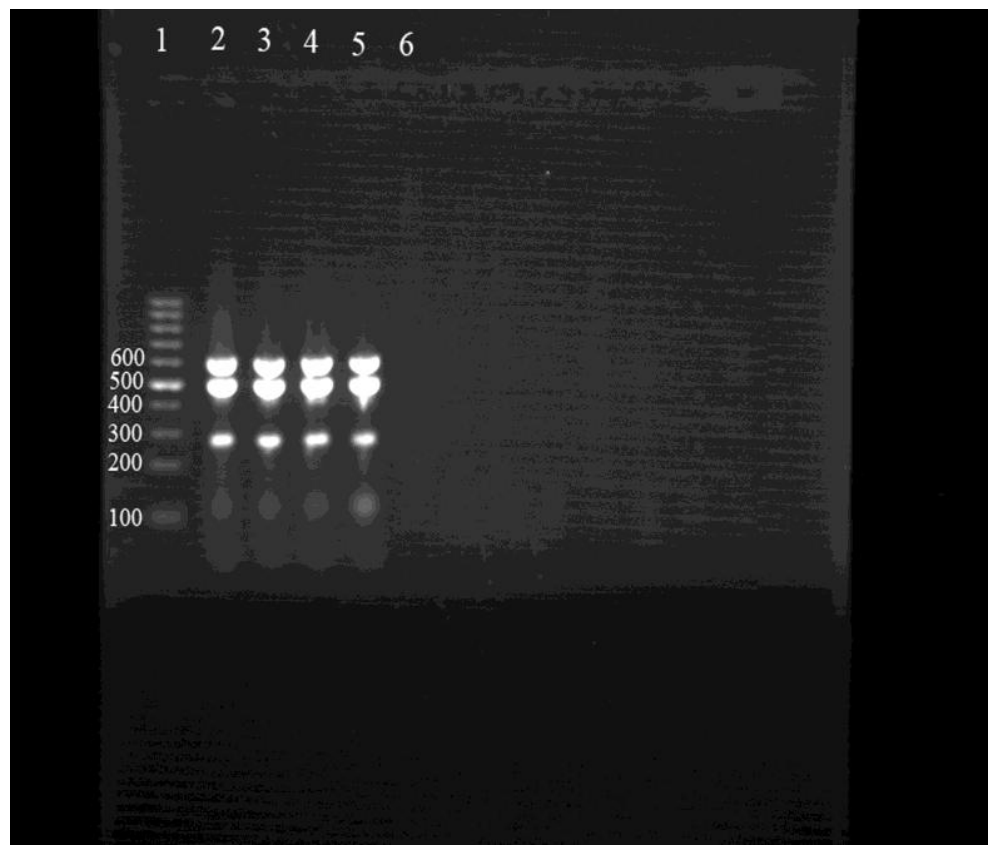

Figure 1. Agarose gel electrophoresis of Multiplex PCR assay for the Identification of E.coli O157:H7. Lane1: 100bp DNA marker, lane 2: E.coli O157:H7 ATCC 43895 (Control positive), lanes 3 - 5: positive samples, lane 6: control negative.

Table 2. Multiplex PCR results of $r f b E$, fliC and uidA in bacterial strains.

\begin{tabular}{llcccc}
\hline Bacterial strain & Serotypes & Isolates & rfbE & flic & uidA \\
\hline Escherichia coli & $\mathrm{O} 157: \mathrm{H} 7$ & 1 & + & + & + \\
& $\mathrm{O} 157: \mathrm{H}^{-}$ & 1 & + & + & + \\
& Other serotypes & 88 & - & - & - \\
Proteus vulgaris & & 2 & - & - & - \\
Enterobacter & & 4 & - & - & - \\
Citrobacter & & 1 & - & - & - \\
\hline
\end{tabular}

positive control strain (Institute Pasteur, Iran).

\section{RESULTS AND DISCUSSION}

From 200 hamburger samples, 8 (4\%) Non-Sorbitol fermenting (NSF) colonies were isolated. Out of the 8 samples, three isolates (1\%) were confirmed as $E$. coli by biochemical tests. The results of multiplex PCR assay confirmed these strains as E. coli O157:H7 (Figure 1) but in one of them, serological tests showed no positive result for the flagellar antigen. The amplicons were sequenced, and the results confirmed with that of Gene bank 0157, H7 flagellar antigen and $\beta$-glucuronidase sequences (data not shown). Other NSF isolates were found to belong to other genus of bacteria (Table 2). Also we detected $88(44 \%)$ Sorbitol fermenting E. coli strains that none of them harbored these three genes.

Many studies have been conducted around the world to determine the presence of $E$. coli $\mathrm{O} 157: \mathrm{H} 7$ in various foods (Hussein and Sakuma, 2005; Hussein, 2007; Ateba and Bezuidenhout, 2008; McEvoy et al., 2003; Fedio et al., 2011). Beef has been estimated as major reservoirs of $E$. coli $\mathrm{O} 157: \mathrm{H} 7$ and plays a significant role in the epidemiology of human infections. hamburgers made with contaminated meat, if they are not sufficiently heated during the cooking process, can cause infection in consumers (You et al., 2006; Dontorou et al., 2003; Bai et al., 2010; Olesen and Jespersen, 2010; Ateba and Bezuidenhout, 2008; Mora et al., 2005; Cieslak et al., 
1997). As Cieslak et al. (1997) showed contaminated hamburgers can be the cause of large outbreaks of $E$. coli $\mathrm{O} 157: \mathrm{H} 7$ infections. In this study, we found that $1 \%$ of the analyzed hamburger samples were contaminated with E. coli O157:H7. Jamshidi et al. (2008) reported that $1 \%$ of ground beef samples were containing $E$. coli O157:H7, but in another study by Jamshidi et al. (2012) it showed $4 \%$ of hamburger samples were contaminated with E. coli O157:H7. The results of studies in the past 3 decades have shown that the prevalent rates of $E$. coli O157:H7 ranged from 0.1 to $54.2 \%$ in ground beef (Hussein, 2007). But a little study performed in our region about the identification and isolation of $E$. coli $\mathrm{O} 157 \mathrm{H} 7$ from food could not provide enough information about the range of prevalence of $E$. coli $\mathrm{O} 157 \mathrm{H} 7$ in food products.

Many protocols for isolation and detection of the $E$. coli O157H7 from food, fecal and environmental samples have been suggested. Conventional culture methods can be useful for isolation of $E$. coli $\mathrm{O} 157 \mathrm{H} 7$. However, the detection of $E$. coli $\mathrm{O} 157 \mathrm{H} 7$ using the current culture methods is time consuming and needs a lot of media and supplement components (Visetsripong et al., 2007). On the other hand, the first isolation of sorbitol-fermenting (SF) O157: $\mathrm{H}$ - was reported during an outbreak of HUS in Bavaria, Germany in 1988 and there is a possibility to get false results by the classic microbiological diagnostic procedures based on screening with sorbitol MacConkey agar (Orth et al., 2009). Currently, various molecular procedures such as PCR are available for detection of $E$. coli O157: H7 specific genes (Hsu et al., 2005). In multiplex PCR, the used of combination primers for the detection of several genes eliminates the possibility of false positives, which may arise if, non-O157:H7 strains were to acquire an O157:H7- specific gene. Although in some strains immunoreactive $\mathrm{H} 7$ flagella antigen is not expressed, but the encoding gene for $\mathrm{H} 7$ flagella antigen is still present within the genome, and may lead to false negative results (Al-Ajmi et al., 2006). We can show the presence of the encoding gene for $\mathrm{H} 7$ flagella Antigen by molecular methods. Al-Ajmi et al. (2006) used a three primer set for detection of 0157 lipolysaccharide $\mathrm{O}$ antigen synthesis gene (perosamine synthetase; $r f b E$ ), $\beta$ glucuronidase (uidA) and $\mathrm{H} 7 \mathrm{fliC}$ gene by multiplex PCR. They reported that these set of primers and multiplex PCR have high sensitivity and specificity to determine the E. coli O157:H7 and O157: $\mathrm{H}-($ Al-Ajmi et al., 2006). The same method was used in the present study and two $E$. coli O157:H7 were detected. Although many multiplex PCR methods have been developed and are widely used, further improvement of the detection procedures is possible as more sequence information becomes available. Examination of food for E. coli O157:H7 with different methods is effective in reducing infections caused by E. coli O157:H7. Further studies to evaluate meat products and to develop fast and economical methods for detection of E. coli O157:H7 particularly in the study region is recommended.

\section{ACKNOWLEDGEMENT}

This work was supported by a grant (No. 88S53) from Research Affairs, Ahvaz Jundishapur University of Medical Sciences, Ahvaz, Iran.

\section{REFERENCES}

Al-Ajmi D, Padmanabha J, Denman SE, Gilbert RA, Al Jassim RMM, Mcsweeney CS (2006). Evaluation of a PCR detection method for Escherichia coli O157: H7/h-bovine faecal samples. Lett. Appl. Microbiol. 42:386-391.

Ateba CN, Bezuidenhout CC (2008). Characterisation of Escherichia coli 0157 strains from humans, cattle and pigs in the North-West Province, South Africa. Int. J. Food. Microbiol. 128:181-188.

Bai J, Shi X, Nagaraja TG (2010). A multiplex PCR procedure for the detection of six major virulence genes in Escherichia coli O157:H7. J. Microbiol. Methods 82:85-89.

Cieslak PR, Noble SJ, Maxson DJ, Empey LC, Ravenholt O, Legarza G, Tuttle J, Doyle MP, Barrett TJ, Wells JG (1997). Hamburgerassociated Escherichia coli O157: H7 infection in Las Vegas: a hidden epidemic. Am. J. Pub. Health 87:176-180.

Dontorou C, Papadopoulou C, Filioussis G, Economou V, Apostolou I, Zakkas G, Salamoura A, Kansouzidou A, Levidiotou S (2003). Isolation of Escherichia coli O157: H7 from foods in Greece. Int. J. Food. Microbiol. 82:273-279.

Fedio WM, Jinneman KC, Yoshitomi KJ, Zapata R, Wendakoon CN, Browning P, Weagant SD (2011). Detection of E. coli O157: H7 in raw ground beef by Pathatrix (TM) immunomagnetic-separation, realtime PCR and cultural methods. Int. J. Food Microbiol. 148(2):87-92.

Hsu CF, Tsai TY, Pan TM (2005). Use of the duplex TaqMan PCR system for detection of Shiga-like toxin-producing Escherichia coli O157. J. Clin. Microbiol. 43:2668-2673.

Hussein HS (2007). Prevalence and pathogenicity of Shiga toxinproducing Escherichia coli in beef cattle and their products. J. Anim. Sci. 85:E63-72.

Hussein HS, Sakuma T (2005). Invited review: prevalence of Shiga toxin-producing Escherichia coli in dairy cattle and their products. J. Dairy Sci. 88:450-465.

Jamshidi AB, Bassami MR, Khanzadi S, Soltaninejad V (2012). Using multiplex-PCR assay in identification of Escherichia coli O157:H7 isolated from hamburger samples in Mashhad, Iran. Iran. J. Nutr. Sci. Food Technol. 35:101-106.

Jamshidi AB, Bassami MR, Rasooli M (2008). Isolation of Escherichia coli O157: H7 from ground beef samples collected from beef markets, using conventional culture and polymerase chain reaction in Mashhad, northeastern Iran. Iran. J. Vet. Res. 9:72-76.

Lee JH, Choi SJ (2006). Isolation and characteristics of sorbitolfermenting Escherichia coli 0157 strains from cattle. Microbes Infect. 8:2021-26.

McEvoy JM, Doherty AM, Sheridan JJ, Thomsona-Carter FM, Garvey P, Mcguire L, Blair IS, Mcdowell DA (2003). The prevalence and spread of Escherichia coli O157: $\mathrm{H} 7$ at a commercial beef abattoir. J. Appl. Microbiol. 95(2):256-266.

Mora A, Blanco JE, Blanco M, Alonso MP, Dhabi G, Echeita A, Gonzalez E A, Bernardez MI, Blanco J (2005). Antimicrobial resistance of Shiga toxin (verotoxin)-producing Escherichia coli 0157:H7 and non-0157 strains isolated from humans, cattle, sheep and food in Spain. Res. Microbiol. 156(7):793-806.

Olesen I, Jespersen L (2010). Relative gene transcription and pathogenicity of enterohemorrhagic Escherichia coli after long-term adaptation to acid and salt stress. Int. J. Food. Microbiol. 141(3):248253.

Orth D, Grif K, Zimmerhackl LB, Wurzner R (2009). Sorbitol-fermenting 
Shiga toxin-producing Escherichia coli $\mathrm{O} 157$ in Austria. Wien. Klin. Wochenschr. 121:108-112.

Visetsripong A, Pattaragulwanit K, Thaniyavarn J, Matsuura R, Kuroda A, Sutheinkul O (2007). Detection of Escherichia coli O157: H7 vt and rfb (0157) by multiplex polymerase chain reaction. Southeast Asian. J. Trop. Med. Pub. Health 38(1):82-90.
You JY, Moon BM, Oh IG, Baek BK, Li LG, Kim BS, Stein BD, Lee JH (2006). Antimicrobial resistance of Escherichia coli 0157 from cattle in Korea. Int. J. Food. Microbiol. 106(1):74-78. 